\title{
Reproductive histories of female humpback whales Megaptera novaeangliae in the North Pacific
}

\author{
C. Scott Baker*, Anjanette Perry, Louis M. Herman \\ Kewalo Basin Marine Mammal Laboratory, University of Hawaii, 1129 Ala Moana Blvd, Honolulu, Hawaii 96814, USA
}

\begin{abstract}
Reproductive histories of individually identified, female humpback whales were documented on both the summering and wintering grounds of an endangered but currently unexploited population. Interbirth or 'calving' intervals of mature females were on average longer and more variable than previously reported, ranging from 1 to at least 5 yr. In Hawaii, multiple sightings of 18 females provided an estimated calving rate (calves [mature female] ${ }^{-1} \mathrm{yr}^{-1}$ ) of 0.58 . In southeastern Alaska, multiple sightings of 41 females provided an estimated calving rate of 0.37 The survival of an individual through at least its first year of life was documented in 5 cases. Three of these, first identified as calves in southeastern Alaska, continued to return to this feeding region as juveniles. The possible weaning of a year-old whale was observed in Hawaii, and the apparent death of a calf was documented in southeastern Alaska. We suggest that the estimated calving rate from sightings of females in Hawaii is inflated by sighting biases and that the lower estimate from southeastern Alaska is a better measure of current reproductive rates. A comparison of this estimate with historical estimates of pregnancy rates from whaling records provides no evidence of a marked density-dependent increase in the reproductive rate of humpback whales.
\end{abstract}

\section{INTRODUCTION}

Commercial whaling has reduced the standing biomass of baleen whales from approximately 45 million tons in the early 1900's to about 9 million tons today (Laws 1977, 1981). In the southern hemisphere alone, this 'liberates' an estimated 153 million tons of krill each year (Laws 1981, Lockyer 1984). It is generally assumed that this tremendous surplus of food resulted in an increase in the reproductive rates of baleen whales during periods of commercial harvesting (Mackintosh 1942, Laws 1961, Gambell 1973, Fowler 1981). Direct evidence of the extent, or even the existence, of these density-dependent changes, however, remains controversial (Mizroch 1980, 1981, Lockyer 1984, Mizroch \& York 1984). Resolving this controversy by determining reproductive rates of endangered or depleted, but currently unexploited, populations of baleen whales is problematic. Historically, the reproductive biology of baleen whales has been described

\footnotetext{
- Present address: Smithsonian Institution, Washington, D.C. 20560, USA
}

only from examination of carcasses in commercial catches. Once a population is protected from commercial harvest, comparable data on subsequent changes in reproductive parameters are difficult to collect. Only in a few protected populations, including the California gray whale Eschrichtius robustus (Rice \& Wolman 1971, Reilly 1984), and the bowhead whale Balaena mysticetus (Nerini et al. 1984), are recent sighting censuses and records of aboriginal or scientific catches available for estimating current population parameters.

The North Pacific humpback whale Megaptera novaeangliae is considered to be one of the most endangered of all baleen whales (Herman \& Antinoja 1977, Johnson \& Wolman 1984). Thought to have numbered between 15000 and 20000 individuals prior to exploitation, intensive 20th century whaling reduced this population to less than 1000 before it was placed under international protection in 1967 (Rice 1974, 1978). Current population estimates range from 1200 to slightly over 2000 individuals (Johnson \& Wolman 1984, Baker et al. 1986, Darling \& Morowitz 1986). Given this tremendous decline in their abun- 
dance, it is plausible that humpback whales now encounter less competition for food and, as a result, have more energy available for reproduction.

Since the litter size of humpback whales is almost inevitably one (Chittleborough 1965), an increase in the reproductive rate of a mature female must occur through a decline in interbirth intervals. Like most baleen whales, humpback whales are seasonal breeders and their reproductive cycles are closely tied to their seasonal migration. A mature female is thought to conceive on the breeding grounds one winter and give birth the following winter (Matthews 1937, Nishiwaki 1959. Chittleborough 1965). The calf is weaned at about 1 yr of age after completing a roundtrip migration to the summer feeding grounds with its mother (Chittleborough 1965). The pregnancy rates of humpback whales in commercial catches indicate that the majority of mature females conceive following the weaning of a calf, resulting in a birth once every $2 \mathrm{yr}$ (True 1904, Matthews 1937, Chittleborough 1958, 1965, Nishiwaki 1959). Alternately, a female may 'rest' for a year following the weaning of a calf, resulting in a 3 yr birth cycle, or a female may conceive immediately after parturition, resulting in a $1 \mathrm{yr}$ birth cycle (Matthews 1937, Chittleborough 1958, Symons \& Weston 1958). Recent observations of yearly births to individually identified females in Hawaii confirm the occurence of $1 \mathrm{yr}$ birth cycles (Glockner-Ferrari \& Ferrari 1984).

Here we present reproductive histories of female humpback whales on the wintering grounds of Hawaii and the feeding grounds of southeastern Alaska. Previous studies have shown that these 2 regions are seasonal habitats of a single population or 'structured stock' (Darling \& Jurasz 1983, Baker et al. 1985, Darling \& McSweeney 1985, Baker et al. 1986). Interbirth or calving intervals were estimated from the presence or absence of an accompanying calf in consecutive seasonal sightings of individually identified females. In a few cases, individual identification was also used to document the survival or mortality of calves during their first year of life and the subsequent migratory destinations of surviving juveniles. A comparison of current calving rates with earlier reports of pregnancy rates from commercial whaling records provides no evidence that the intense exploitation of this population has resulted in a marked increase in reproduction through a decline in interbirth intervals.

\section{METHODS}

Photographic documentation. Humpback whales were observed from small vessels and photographed with $35 \mathrm{~mm}$ single-lens reflex cameras equipped with $300 \mathrm{~mm}$ telephoto or 70 to $210 \mathrm{~mm}$ zoom lenses. High- speed black-and-white or color film was used to obtain clear photographs to the ventral surface of each whale's tail flukes for the purpose of individual identification (Katona et al. 1979, Baker \& Herman 1984a). From each sighting of a whale or group of whales, the best photograph of each individual was assigned a 'fluke observation' number (Baker et al. 1986). Information on the location and date of sighting of a fluke observation, as well as the reproductive role and social affiliation of the identified whale, was stored in a data retrieval file at the University of Hawail Computing Center. During the matching of fluke photographs, a whale that was sighted on more than one occasion was also assigned an 'animal' number which allowed all fluke observations, or sightings, of that individual to be referenced. Each individual discussed here was sighted more than once and is referred to by its animal number.

Study locations and periods. Research effort was concentrated in 2 seasonal habitats of humpback whales in the central and eastern North Pacific: Hawaii and southeastern Alaska. The main Hawaiian Islands are thought to be the numerically most important of the 3 known winter breeding and calving grounds of humpback whales in the North Pacific (Herman \& Antinoja 1977. Wolman \& Jurasz 1977). Across a 7 yr study period, an estimated 1320 to 1934 individual humpback whales visited the Hawaiian Islands (Baker et al. 1986). Possibly half this number may visit Hawaii in a single winter season (Wolman \& Jurasz 1977 , Darling et al. 1983j. Southeastern Alaska, including the Alexander Archipelago, is currently the best studied feeding region in the North Pacific (Baker et al. 1985, Darling \& McSweeney 1985). An estimated 270 to 372 humpback whales spend much of the summer and fall feeding in the protected inside waters of this region (Baker et al. 1985).

Individual identification photographs were collected in Hawail during 1978 to 1984 from late January to early April, the period of peak seasonal abundance (Herman \& Antinoja 1977, Baker \& Herman 1981). Photographs were collected in southeastern Alaska throughout the summers of 1980 to 1985 (Baker et al. 1985). Some observations from previous and subsequent seasons were included when available.

Gender and reproductive status. The gender and reproductive status of female humpback whales were inferred from the presence of an accompanying calf during one or more sightings. Because of the close association between a cow and her calf during most of the calf's first year, it was usually possible to identify the cow even when other adults were present in a pod. The fact that cow-calf pairs never associate with other pairs in Hawaii (Herman \& Antinoja 1977), and only rarely in southeastern Alaska (Baker 1985), helped to prevent confusion about the mother of an individual calf. 
To facilitate the interpretation of results, the following terms were standardized in this study:

Cow. An adult female accompanied by a calf in either Hawaii or southeastern Alaska.

Calf. A whale approximately 3 to $4 \mathrm{~m}$ in length and assumed to be newborn when sighted during January to March in Hawaii, or approximately 4 to $5 \mathrm{~m}$ in length and assumed to be 5 to 7 mo old when sighted during June to August in southeastern Alaska.

Yearling. A whale first identified as a calf and assumed to be at least 1 yr old on its return to Hawaii or southeastern Alaska the following year.

Juvenile. A whale first identified as a calf and subsequently sighted as a 2 or 3 yr old.

Calving intervals. The number of years between seasons in which an individually identified female was accompanied by a calf. 'Bounded' and 'unbounded' calving intervals are further distinguished in the text.

Calving rates. The proportion of individually identified females, assumed to be sexually mature, accompanied by calves in a given year or summed across years and expressed on a per-year basis. The calving rate of an individual female is equal to the inverse of her calving interval.

Pregnancy rates. As reported in catch statistics of the commercial whaling industry, the proportion of pregnant females in the total catch of mature females (Lockyer 1984). 'Apparent' and 'true' pregnancy rates are further distinguished in the text.

Crude birth rates. The percentage of calves in the total population or sample of a population.

\section{RESULTS}

\section{Sighting histories}

Of the 1230 whales individually identified in either Hawaii or southeastern Alaska during this study, 119 were inferred to be reproductively mature females based on their close association with a calf in one or more years. Forty-seven females were sighted only in southeastern Alaska, 59 were sighted only in Hawaii, and 13 were common to both regions. Because of potential differences due to biases in data collection the sighting records of females from each seasonal habitat are considered separately.

Female whales were resighted across years far more frequently in southeastern Alaska than in Hawaii. Of the 60 females identified in southeastern Alaska, 41 $(68 \%)$ were sighted in more than one year and 4 females were sighted in all 6 study years (Table 1 ). In Hawaii, only $18(25 \%)$ of the 72 identified females were sighted across more than one year and only one female was seen in more than 2 of the 7 study years (Table 2).

\section{Calving intervals}

Records of females sighted across more than a single year provided information on calving intervals of individual humpback whales. Because sighting histories were seldom continuous, it was necessary to distinguish 'bounded' calving intervals from 'unbounded' calving intervals. A bounded interval was based on the consecutive sightings of a female which were bounded by both her previous and subsequent sightings with a calf. An unbounded interval was based on the consecutive sightings of a female which were unbounded either by her previous or by her subsequent sighting with a calf. In an unbounded interval, it was assumed that the female was accompanied by a calf in the missing year of the sighting record. An unbounded sighting of a female without a calf was assumed to be a 2 yr unbounded interval. As a consequence of this assumption, unbounded intervals are only a minimum estimate of the true calving interval. Animal \#530 (Case 31, Table 1), for example, was sighted in southeastern Alaska across 5 consecutive seasons. A bounded 2 yr interval is indicated by the presence of a calf in 1982, the absence of a calf in 1983 , and the presence of the next calf in 1984. An unbounded $2 \mathrm{yr}$ interval is indicated by the absence of a calf in 1981. A second unbounded $2 \mathrm{yr}$ interval is indicated by the absence of a calf in 1985 .

\section{Southeastern Alaska}

The 138 sightings of females in southeastern Alaska (Table 1) provided records of 65 calving intervals. Only 4 calving intervals were bounded: 2 intervals were 2 yr, 1 was $3 y r$, and 1 was 1 yr. The 61 unbounded intervals included 47 of $2 \mathrm{yr}, 10$ of $3 \mathrm{yr}, 2$ of $4 \mathrm{yr}, 1$ of $5 \mathrm{yr}$, and 1 of $7 \mathrm{yr}$.

The previous work of Jurasz \& Palmer (1981) provides additional information on the 2 females accounting for the longest calving intervals. Animal \#166 (Case 6, Table 1), nicknamed 'Frenchie', was sighted with a calf in 1974 (Jurasz \& Palmer 1981). Assuming that Jurasz \& Palmer (1981) correctly identified \#166 as the mother, her $6 y r$ sighting record indicates a minimum calving interval of $7 \mathrm{yr}$. Animal \#587 (Case 8, Table 1), nicknamed 'Gertrude', was first sighted in 1973 and subsequently sighted with a calf in 1977 (Jurasz \& Palmer 1981, Perry et al. 1985). She was sighted without a calf throughout the summers of 1980 to 1983 and 1985 but returned to southeastern Alaska with a calf in 1984. This sighting record indicates a minimum calving interval of $5 \mathrm{yr}$. 
Table 1. Megaptera novaeangliae. Reproductive histories of female humpback whales sighted during more than one year in southeastern Alaska. C: calf present, $A$ : calf absent in that sighting year

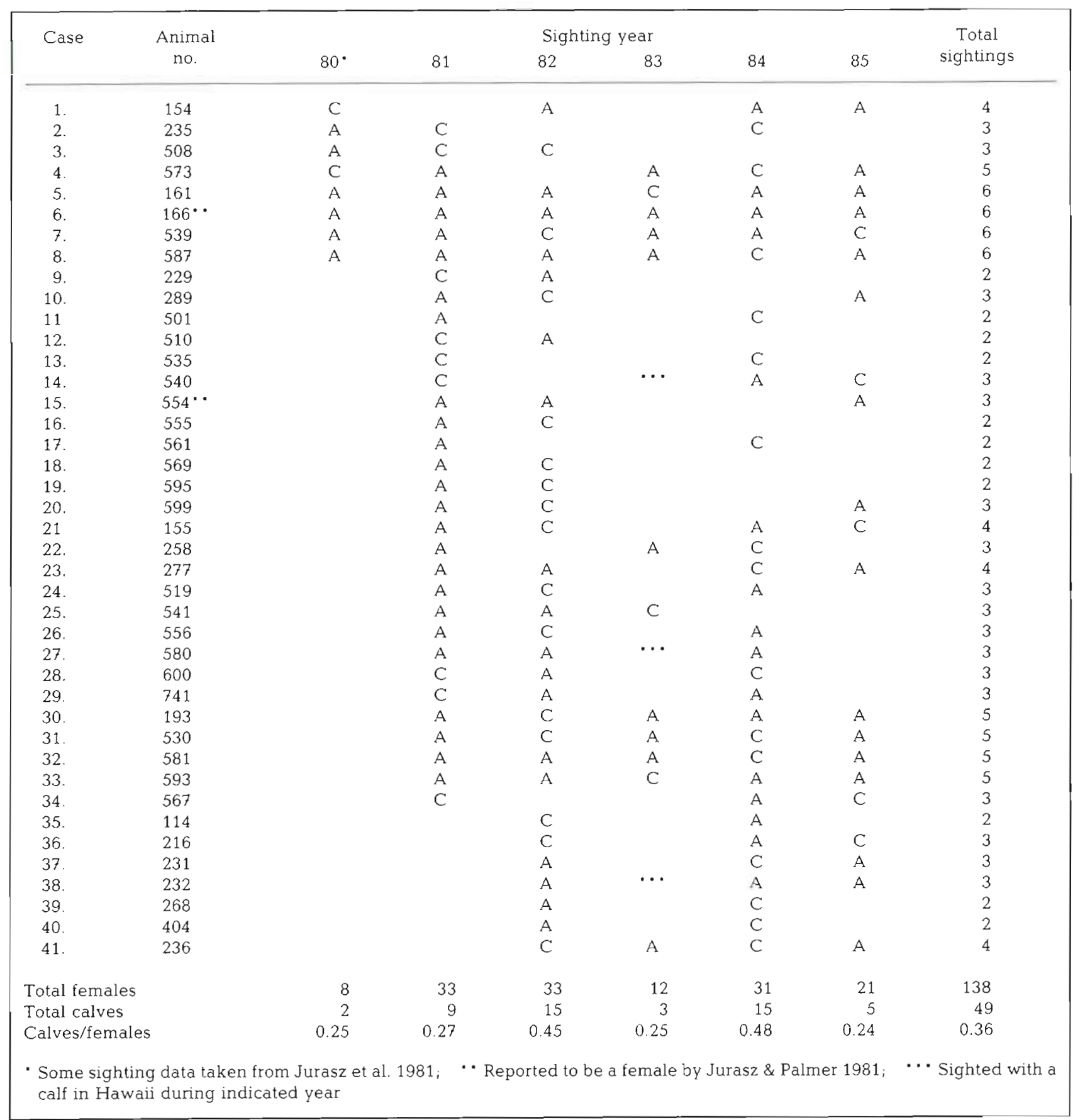

Hawaii

The 40 total sightings of Hawaiian females (Table 2) include 1 bounded 2 yr interval, 1 bounded 1 yr interval, and 15 unbounded 2 yr intervals.

\section{Calving rates}

If resight histories were complete, the average calving rate would simply be the inverse of the average calving interval. Unfortunately, the number of bounded calving intervals is presently too small to estimate calving rates. An estimate of calving rates based on 
Table 2. Megaptera novaeangliae. Reproductive histories of female humpback whales sighted during more than one year in Hawaii C: calf present; A: calf absent in that sighting year

\begin{tabular}{|c|c|c|c|c|c|c|c|c|c|}
\hline \multirow[t]{2}{*}{ Case } & \multirow{2}{*}{$\begin{array}{c}\text { Animal } \\
\text { no. }\end{array}$} & \multicolumn{7}{|c|}{ Sighting year } & \multirow{2}{*}{$\begin{array}{c}\text { Total } \\
\text { sightings }\end{array}$} \\
\hline & & 78 & 79 & 80 & 81 & 82 & 83 & 84 & \\
\hline 1. & 062 & C & & & $\mathrm{C}$ & & & & 2 \\
\hline 2. & 424 & A & & & & C & & & 2 \\
\hline 3. & 075 & & $\mathrm{C}$ & & $\mathrm{C}$ & & & & 2 \\
\hline 4. & 370 & & A & & & & & $\mathrm{C}$ & 2 \\
\hline 5. & 011 & & & C & & & $\mathrm{C}$ & & 2 \\
\hline 6. & 100 & & & A & & & C & & 2 \\
\hline 7. & 071 & & & C & A & C & & A & 4 \\
\hline 8. & 082 & & & & A & & $\mathrm{C}$ & & 2 \\
\hline 9. & 114 & & & & A & $\cdot$ & A & & 2 \\
\hline 10. & 117 & & & & $A$ & & & $\mathrm{C}$ & 2 \\
\hline 11. & 245 & & & & C & $\mathrm{A}$ & & & 2 \\
\hline 12. & 346 & & & & & A & $\mathrm{C}$ & & 2 \\
\hline 13. & 354 & & & & & $\mathrm{C}$ & & A & 2 \\
\hline 14. & 432 & & & & & $\mathrm{C}$ & & A & 2 \\
\hline 15. & 355 & & & & & & A & $\mathrm{C}$ & 2 \\
\hline 16. & 365 & & & & & & $C$ & A & 2 \\
\hline 17 & 442 & & & & & & $\mathrm{C}$ & $\mathrm{C}$ & 2 \\
\hline 18. & 540 & & & & & & C & A & 2 \\
\hline \multicolumn{2}{|c|}{ Total females } & 2 & 2 & 3 & 7 & 6 & 9 & 9 & 38 \\
\hline \multicolumn{2}{|c|}{ Total calves } & 1 & 1 & 2 & 3 & 4 & 7 & 4 & 22 \\
\hline \multicolumn{2}{|c|}{ Calves/females } & 0.50 & 0.50 & 0.66 & 0.43 & 0.66 & 0.77 & 0.44 & 0.58 \\
\hline
\end{tabular}

unbounded calving intervals would be biased by the assumption that all females gave birth in years that they were not sighted. We chose instead to estimate yearly calving rates by dividing the number of sightings of females with calves by the total number of sightings of females with or without calves. This estimate makes no assumption about the presence or absence of a calf during years when an individual female was not sighted. It does assume, however, that the chances of sighting a female were not affected by the presence or absence of a calf.

\section{Southeastern Alaska}

The calving rates of females in southeastern Alaska showed considerable year-to-year variation, ranging from a high of 0.48 (calves [mature female] ${ }^{-1} \mathrm{yr}^{-1}$ ) in 1984 to a low of 0.24 in 1985 (Table 1). During the years 1981 to 1985 , calving rates appeared to change cyclically with high rates in even years and low rates in odd years. Although these changes were substantial, overall differences across the 6 study years were not statistically significant (Test of Independence, Chi-square [5] = $6.87, \mathrm{p}=0.23$ ). Based on all years combined, the calving rate in southeastern Alaska was 0.36 with $95 \%$ binomial confidence limits of 0.27 to 0.45 (with a normal approximation, Snedecor \& Cochran 1967). If the sighting record of Animal \#166 was excluded as a possible misidentification, the calving rate increased slightly, to 0.37 (95\% binomial confidence limits, 0.28 to 0.46 ).

Hawaii

The estimates of calving rates in Hawaii were considerably higher than those from southeastern Alaska (Table 2). Only 1981 and 1984 showed a calving rate of less than 0.50. Year-to-year differences in Hawaiian calving rates were not significant (Test of Independence with 1978, 1979, and 1980 combined as a single class, Chi-square $[4]=2.97, p=0.56$ ). Based on all years combined, the calving rates of females in Hawaii was 0.58 (95\% binomial confidence limits, 0.41 to 0.75 ).

\section{Calf survival and mortality}

The survival of a calf through at least its first year of life was documented in 5 cases (Table 3). Three calves (\#072, 1072, and 416), identified by their flukes or distinctive dorsal fins, were observed as yearlings while still accompanied by their mothers in Hawaii. For the 2 individuals seen in Hawaii as both calves and yearlings, the minimum period of association with the cow was $345 \mathrm{~d}$ (Animal \#072) and $371 \mathrm{~d}$ (\#1072). A fourth indi- 
Table 3. Megaptera novaeangliae. Documented survival of humpback whale calves subsequently sighted as yearlings and juveniles in Hawaii $(\mathrm{HI})$ or southeastern Alaska (AK)

\begin{tabular}{|c|c|c|c|c|c|}
\hline \multirow{2}{*}{$\begin{array}{c}\text { Animal } \\
\text { no }\end{array}$} & \multicolumn{2}{|c|}{ Calf with cow } & \multicolumn{3}{|c|}{ Juvenile alone } \\
\hline & First & Last & Age 1+ & Age $2+$ & Age 3+ \\
\hline $072^{1}$ & Mar $80(\mathrm{HI})$ & Feb $81(\mathrm{HI})$ & - & - & - \\
\hline $1072^{2}$ & Mar $81(\mathrm{HI})$ & Mar $82(\mathrm{HI})$ & - & - & - \\
\hline $198^{3}$ & Jul $82(A K)$ & Dec $82(\mathrm{AK})$ & - & Jul $84(\mathrm{AK})$ & Aug 85 (AK) \\
\hline $186^{4}$ & Aug $82(\mathrm{AK})$ & - & - & Aug 84 (AK) & Aug $85(A K)$ \\
\hline $416^{5}$ & Sep $83(A K)$ & Feb $84(\mathrm{HI})$ & Jul $84(\mathrm{AK})$ & Aug 85 (AK) & - \\
\hline
\end{tabular}

vidual, \#198, first sighted as a calf on $11 \mathrm{Jul} 1982$, was still accompanied by its mother in southeastern Alaska on 5 Dec 1982 (Baker et al. 1985).

One case of possible weaning was documented in Hawaii. Animal \#072 was first observed as a newborn calf with its mother (\#071) near Maui on 6 Mar 1980 (also described in Baker \& Herman 1984a). The following year Animal \#072, then a yearling, and its mother were observed across a $3 \mathrm{~d}$ period near the Big Island. On the first $2 \mathrm{~d}$ the yearling was sighted with the female and another adult. Field researchers did not recognize \#072 on sight but one of the authors (CSB) did note that it was small and suggested that it might be a yearling. On the second day the yearling, female, and adult 'escort' were observed for over $5 \mathrm{~h}$ during which they repeatedly tail-slapped, flipper-slapped, and breached, sometimes in tandem. On the third day the female was seen alone.

Another yearling, still accompanied by its mother in Hawaij, was involved in surface activity associated with aggression and male-male competition for females (Tyack \& Whitehead 1983, Baker \& Herman 1984a). Animal \#1072 was sighted as a newborn calf with its mother, \#245, near Maui during winter 1981. The cowcalf pair was sighted the following summer (1981) in southeastern Alaska and again in Hawaii on $9 \mathrm{Mar}$ 1982. On this last sighting date the cow and yearling were accompanied by an adult male, \#022 (Baker \& Herman 1984a), and another adult of unknown sex. All the whales accompanying the female, including the yearling, were headlunging and apparently attempting to displace each other away from the cow. As with Animal \#072, field researchers did not recognize \#1072 and, in this case, assumed that it was an adult.

Two of the 4 yearlings (\#198 and 416), and a fifth calf (\#186), not sighted as a yearling, have been resighted as juveniles in southeastern Alaska. Although the characteristic pattern of coloration on the ventral surface of the flukes may change, sometimes dramatically, during the first few years of a whale's life (Jurasz \& Palmer 1981, Carlson \& Mayo 1983), this is not always the case. The fluke coloration of juveniles discussed here was distinct when each individual was first photographed in southeastern Alaska at 6 to 9 mo of age (Fig. 1). To date, their fluke colorations have remained relatively stable and recognizable.

A single case of apparent calf mortality was documented during summer 1986 (Baker 1986). Animal \#587 (Case 8, Table 1) was sighted with a newborn calf on 3 Mar 1986, in Hawaii. The pair returned to Glacier Bay, southeastern Alaska that summer and were observed together on 3 separate occasions in June. Animal \#587, unaccompanied by her calf, was next sighted in the waters adjacent to Glacier Bay during early August. She remained there alone for the rest of August and early September. Given the calf's age (approximately 4 to 6 mo) and small size (about $3 \mathrm{~m}$ ), its disappearance in June is unlikely to have been a case of early weaning. Although the cause is unknown, it seems more likely that the calf died sometime between the last sighting of the pair in late June and the first sighting of \#587 alone in early August.

\section{DISCUSSION}

\section{Calf survival and migratory return}

Documenting the survival of 5 calves through their first year of life and beyond is an initial step in developing complete life tables for humpback whales in the North Pacific. Three cases, including the one reported earlier by Baker \& Herman (1984a), showed the migratory return of a yearling with its mother to Hawail. In one case, the yearling separated from the cow following a strenuous episode of aerial behavior lasting over $5 \mathrm{~h}$. It is possible that the calf's departure was an instance of weaning and that the preceding aerial activity was the result of the cow's refusal to nurse. Similar parent-offspring conflicts are common during weaning in some ungulates (Leuthold 1977). These observations provide direct evidence that, in general, 


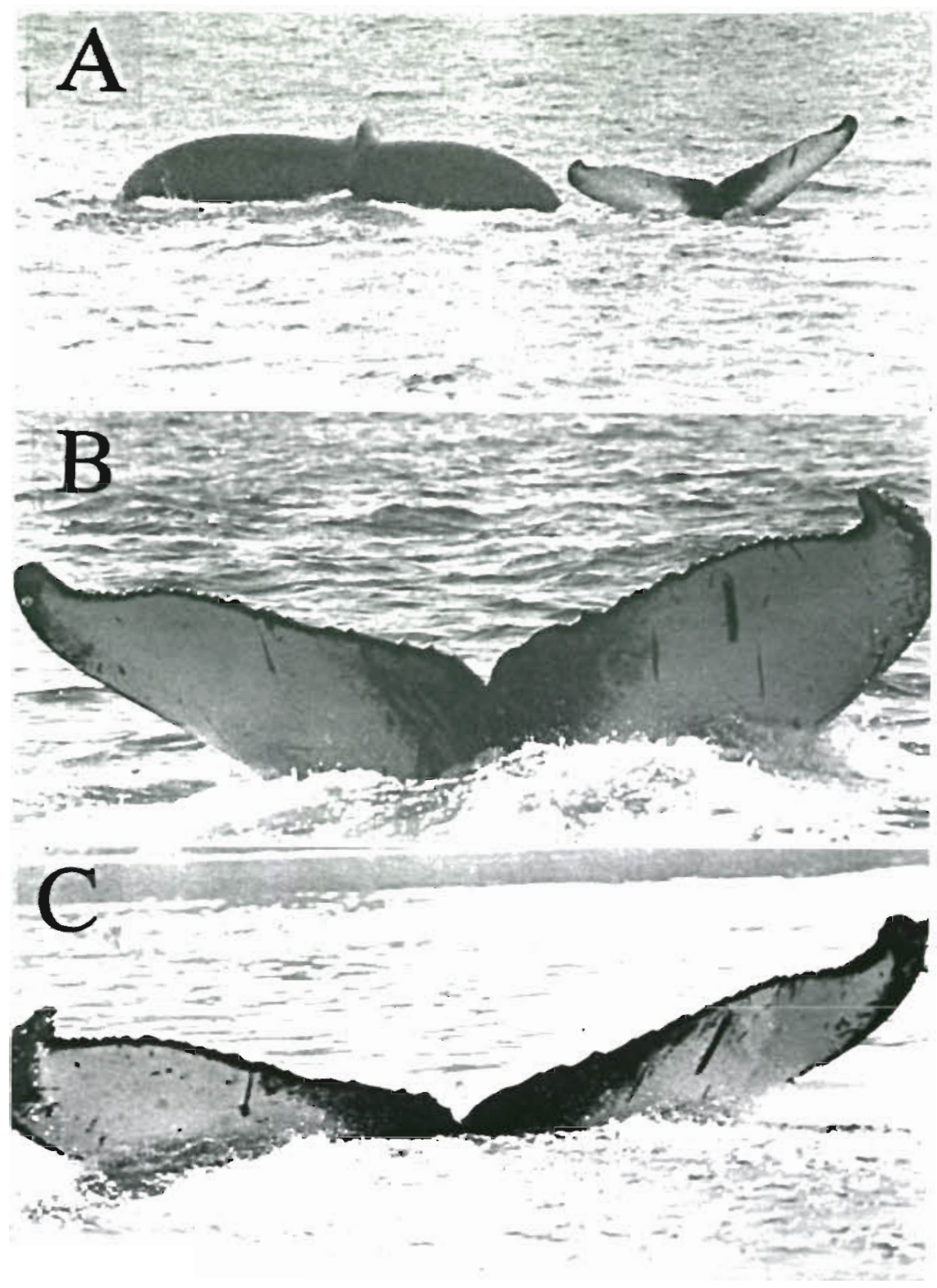

Fig. 1. Megaptera novaeangliae. Stability of fluke coloration during maturation. A: Animal \#416, at age 6 to 8 mo (approximately), accompanied by its mother (Animal \#541) on 4 Sep 1983, in southeastern Alaska. B: At age 12 to 14 mo and accompanied by its mother on 3 Feb 1984, in Hawaii. C: At age 2.5 yr and alone on $15 \mathrm{Jul}$ 1985, in southeastern Alaska

calves are completely weaned at about 1 yr of age, and separate from their mothers on their return to the wintering grounds. Some variability in this pattern, however, is indicated by Clapham \& Mayo's (in press) observations of 48 calves which returned, as yearlings, to the Stellwagen Bank of the North Atlantic. Three of these yearlings remained associated with, or reassociated with, their mothers for a second summer.

Maternally-directed fidelity to a feeding region was indicated by the migratory return of yearlings and juveniles to southeastern Alaska. Jurasz \& Palmer (1981) earlier reported the return of a 2 yr old indi- vidual, nicknamed 'Garfuncle', to Glacier Bay, southeastern Alaska. Garfuncle has continued returning to the Glacier Bay area for 10 of the 12 summers since its birth in 1974 (Jurasz \& Palmer 1981, Perry et al. 1985. Baker 1986). Clapham \& Mayo's (in press) observations of returning yearlings and juveniles indicate a similar fidelity on the feeding grounds of the North Atlantic.

The site-fidelity demonstrated by juveniles and their mothers could underlie the formation of segregated feeding 'herds' in both oceans (Whitehead 1982, Martin et al. 1984, Baker et al. 1985, Baker et al. 1986, Clapham \& Mayo in press). Within a feeding herd, the 
tendency for neighboring whales to be closely related could enhance the benefits of cooperative or non-competitive feeding strategies (Baker \& Herman 1984b, Baker 1985). The formation of maternal kinship groups, however, has not yet been documented. Although often found within a few kilometers of each other, we have not observed juveniles associating directly with their mothers.

\section{Accuracy of regional calving rates}

Other available data indicate that our estimated calving rate from individually identified females in Hawaii $\left.(0.58 \text { calves [mature female }]^{-1} \mathrm{yr}^{-1}\right)$ is inflated. Aerial surveys during the peak of seasonal abundance in 1976 indicate that, at best, 9.1 to $9.6 \%$ of the humpback whales sighted in Hawail were calves (Herman \& Antinoja 1977). Assuming that, with the inclusion of newborn calves, half of the individuals in the population are females and approximately half are mature (Nishiwaki 1959, Herman \& Antinoja 1977), a crude birth rate of $9.6 \%$ suggests a calving rate of 0.38 (9.6/ [100 × 0.50 $\times 0.50 \mathrm{l}=0.38$ ). Across all aerial surveys conducted throughout the winter seasons of 1978 to 1980 , only $7.2 \%$ of the 1407 individuals sighted were calves (Bauer 1986), suggesting a calving rate of only 0.29 .

Inflated calving rates from individually identified females in Hawaii could be the result of behavioral characteristics which increase the probability of sighting a female during the years that she is accompanied by a calf. Early in the winter season, pods with newborn calves surface more often and remain closer to the shoreline than adult pods (Herman \& Antinoja 1977. Glockner-Ferrari \& Venus 1983). As the season progresses, cow-calf pairs are frequently at the center of conspicuous aggregations of male 'escorts' competing for proximity to the cow (Herman \& Antinoja 1977 . Tyack \& Whitehead 1983, Baker \& Herman 1984a). Finally, cow-calf pairs, as a class, tend to remain longer on the wintering grounds than resting or newly pregnant females (Chittleborough 1965, Dawbin 1966, Herman \& Antinoja 1977).

Many of the positive biases affecting the accuracy of estimated calving rates in Hawaii do not affect those from southeastern Alaska. The seasonal residency of whales in southeastern Alaska is prolonged and relatively less influenced by age-sex differences in migratory timing (Baker et al. 1985). The smaller seasonal population and the high probability of yearly return to southeastern Alaska helps assure that individuals are seen repeatedly and continuously across several years, regardless of the presence or absence of a calf (Baker et al. 1985, Baker et al. 1986).

Inevitably, measurements of calving rates in south- eastern Alaska, and other feeding grounds (Clapham \& Mayo in press), will be influenced by an unknown degree of neonatal mortality during the first few months of life. The apparent loss of a calf during migration between Hawaii and southeastern Alaska, reported previously (Baker et al. 1985), and the apparent loss of a calf in southeastern Alaska during the summer of 1986 , reported here, are evidence of at least some mortality during this period. A direct estimate of neonatal mortality would be possible with more sighting records of individually identified females on both the summer and winter grounds. Regardless of its magnitude, however, neonatal mortality does not affect the accuracy of the estimated calving rate from a feeding ground, only the ability to compare this estimate to other measures of reproduction.

Some negative bias in the estimated calving rate from southeastern Alaska could result from the inadvertent inclusion of yearly sighting records prior to a female's sexual maturity. This potential bias, however, could have little impact on the 1984 and 1985 data, when all but a few of the females were known to have given birth in previous years. The calving rate estimated from only the last 2 study years (20 calves $/ 52$ yearly sightings of females $=0.38$ ), is consistent with the estimate from all sample years combined. Thus, we consider the overall calving rate of 0.37 (95\% binomial confidence limits, 0.28 to 0.46 ) to be accurate and suggest that, on average, a mature female gives birth only once every $2.7 \mathrm{yr}$ to a calf that survives its first 6 mo of life and its first migratory transit.

\section{Historical comparisons}

Do current calving rates of humpback whales in the North Pacific indicate a density-dependent increase in reproduction? If all reproductive measurements were collected concurrently and with complete accuracy, calving rates should be equal to pregnancy rates minus the intervening rates of fetal reabsorption, stillbirths, and neonatal mortality. Current calving rates that are equal to or larger than historic pregnancy rates would thus be evidence of some density-dependent increase in reproduction. A summary of data from exploited populations of humpback whales suggests that this is not the case (Table 4 ). The estimated calving rate from southeastern Alaska is lower than all previously reported pregnancy rates except those of Chittleborough (1965) from western Australia.

The relatively low calving rate from southeastern Alaska is more disturbing when the conservative biases in historical pregnancy rates are also considered (Lockyer 1984). Since international regulations (dating from 1933) prohibit the capture of cows accompanied by a 
Table 4. Megaptera novaeangliae. Reported 'apparent' and 'true' or adjusted pregnancy rates of humpback whales from commercial catch statistics

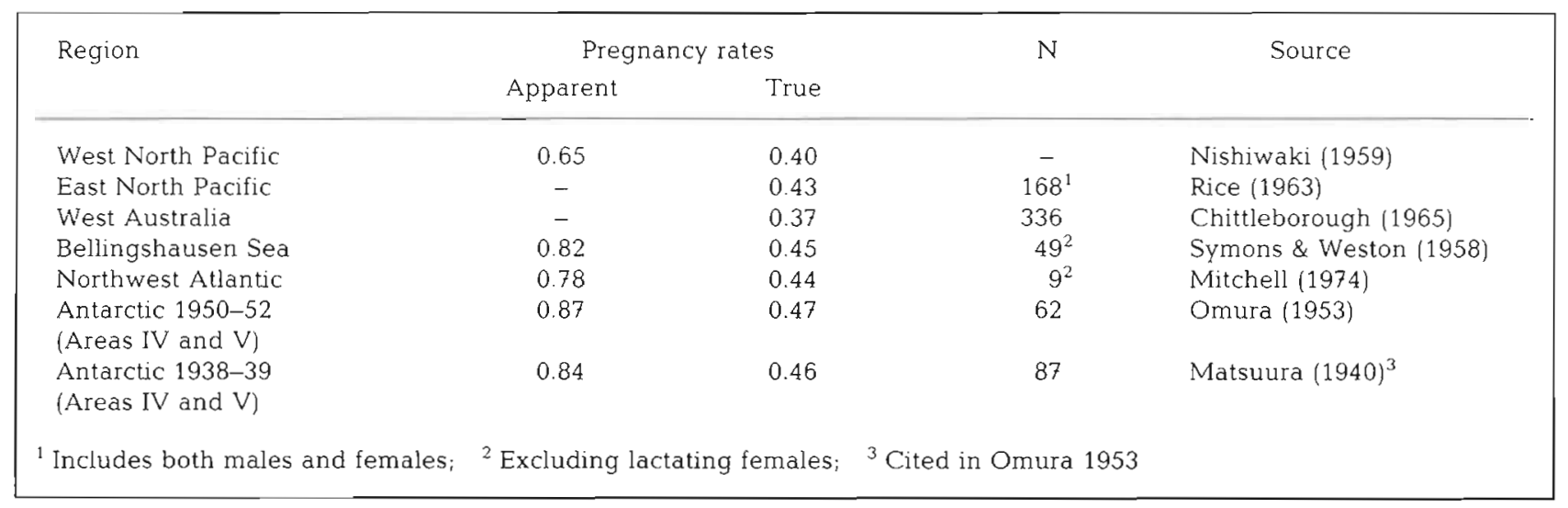

calf, catch statistics reflect only 'apparent' pregnancy rates. To calculate 'true' or adjusted pregnancy rates, whaling biologists assumed that the unsampled number of females with a calf was equal to the sampled number of pregnant females (Symons \& Weston 1958, Nishiwaki 1959, Rice 1963, Chittleborough 1965, Mitchell 1974). This calculation excluded an unknown proportion of cows that may have been giving birth on a yearly cycle, thus resulting in an underestimate of actual pregnancy rates (Lockyer 1984).

Even in the absence of historical comparisons, the length and variability of calving intervals observed in southeastern Alaska is direct evidence that these females are not currently approaching their maximum reproductive potential. In fact, interbirth intervals of this length (up to at least $5 \mathrm{yr}$ ) have not been reported previously for this species. Whaling biologists tended to assume that a female would 'rest' for no more than a single year after weaning a calf. The possibility of a female resting for more than a single year or experiencing non-fertile ovulations has not been generally considered.

What can explain the apparent depression in reproductive rates of this depleted but currently unexploited population of baleen whales? The following 5 hypotheses are among the most plausible:

(1) Density-dependent changes in recruitment are occuring in other population parameters. Eberhardt (1977) suggests that, among Iong-lived species, changes in food availability are likely to affect juvenile mortality and age of first reproduction before affecting birth rates and adult mortality.

(2) Populations are below a 'threshold' where reproduction is depressed or inhibited by low density. In some species with a colonial mating system, reproduction is facilitated by a high density of conspecifics (Wilson 1975). Known as the 'Fraser Darling effect', social facilitation of mating may be a factor in hump- back whale wintering aggregations (Baker \& Herman 1984a).

(3) Other species of marine mammals or birds have expanded their niche and displaced whales through interspecific competition. In the southern hemisphere, several species of seals and penguins may now utilize prey once taken by baleen whales (Laws 1977, Payne 1977). Mitchell (1975) suggests that other species of baleen whales may have competitively displaced right whales in the North Atlantic.

(4) Potential density-dependent increases in reproductive rates are being offset by other factors. A severe population 'bottleneck', caused by intensive exploitation, can reduce the genetic variability of a population, potentially resulting in decreased fertility and increased juvenile mortality (Bonnel \& Selander 1974, Ralls et al. 1979, O'Brien et al. 1983). Environmental contaminants, particularly chlorinated hydrocarbons, are reported in the tissue of most marine mammals and have been implicated in the reduced reproductive success of some species (Delong et al. 1973, Helle et al. 1976). Chronic human disturbance or displacement from preferred habitats could stress individuals (Norris \& Reeves 1978, Herman et al. 1980, Baker et al. 1982), resulting in disruption of pregnancy or a reduction in the amount of energy available to females for reproduction (Laws 1973, Herrenkohl 1979).

(5) The predominant factors controlling the growth of baleen whale populations are independent of density (Mizroch 1983). There are few observations of humpback whales that suggest direct intraspecific competition for access to food; an important mechanism of density-dependent regulation in a population. This does not, however, argue against the importance of food availability in limiting humpback whale reproduction. Undoubtedly, the energetic demands of pregnancy and lactation on female baleen whales are extreme (Lockyer 1981, 1984). However, a female's 
ability to gather sufficient food for reproduction may be determined primarily by yearly changes in the number or rate of formation and dispersal of prey patches, rather than by intraspecific competition or population density.

Assessment of humpback whale forage in southeastern Alaska shows significant regional, seasonal, and yearly differences in the abundance of prey species (Bryant et al. 1981, Krieger \& Wing 1984). Marked yearly changes in the calving rates from southeastern Alaska, although not statistically significant with our sample size, could be the result of 'lean' and 'fat' years of prey availability. Alternatively, cyclical changes in the calving rates of neighboring females could be influenced by behavioral or social synchrony that is only loosely determined by environmental cycles.

At present, it is not possible to conclude which, if any, of these hypotheses correctly explains the apparent depression in reproductive rates of North Pacific humpback whales. Only the continued long-term study of naturally marked individuals in this, and other baleen whale, populations will provide the accurate measurements of population parameters necessary for an enlightened management policy and for a truly comparative study of life-history strategies in these species.

Acknowledgements. The final analysis of these data and the preparation of this manuscript were conducted with funding from Cooperative Agreement No. CA-9700-3-8028 between the National Park Service, Alaska Regional Office, and the University of Hawaii at Manoa. The research summarized here was supported in part by grants and contracts to L. M. Herman or C. S. Baker from the National Park Service, the National Marine Fisheries Service, the National Wildlife Federation, the Center for Field Research, the University of Hawaii Sea Grant College Program, and the National Science Foundation. Surveys of humpback whales throughout southeastern Alaska during 1984 and 1985 were made possible through the cooperation of personnel from Glacier Bay National Park and the Auke Bay Laboratory, National Marine Fisheries Service. The views and opinions expressed in this paper do not necessarily reflect those of these agencies.

We thank the following people for their assistance in the field or during the analysis of data: Gordon Bauer, Brooks Bays, Pierre Dawson, Adam Frankel, Paul Forestell, Thomas Kieckhefer, Joseph Mobley, Don and Signey Pearson, Janice Straley, William Stifel, and Barbara Taylor. We thank the following people and agencies for logistical support: AI Lovaas, National Park Service, Alaska Regional Office; Michael Tollefson and Gary Vequist, Glacier Bay National Park; Ken Krieger, Dr George Snyder, and Dr Bruce Wing, Auke Bay Laboratory; Dr Linda Jones, Dr. Michael Tillman, Allen Wolman; and the late Jim Johnson, National Marine Mammal Laboratory, National Manne Fisheries Service. Sally Mizroch, National Marine Mammal Laboratory, provided stimulating discussion about the reproductive rates of baleen whales.

\section{LITERATURE CITED}

Baker, C. S. (1985). Population structure and social organization of humpback whales (Megaptera novaeangliae) in the central and eastern North Pacific. Ph. D. dissertation, Univ. of Hawau, Honolulu

Baker, C. S. (1986). Population characteristics of humpback whales in Glacier Bay and adjacent waters: summer 1986 Report to Glacier Bay National Park and Preserve, Gustavus

Baker, C. S., Herman, L. M. (1981). Migration and local movement of humpback whales through Hawaiian waters. Can J. Zool. 59: 460-469

Baker, C. S., Herman, L. M. (1984a). Aggressive behavior between humpback whales, Megaptera novaeangliae, wintering in Hawaiian waters. Can. J. Zool. 62: 1922-1937

Baker, C. S., Herman, L. M. (1984b). Seasonal contrasts in the social behavior of humpback whales. Cetus 5: 14-16

Baker, C. S., Herman, L. M., Bays, B. G., Stifel, W. S. (1982). The impact of vessel traffic on the behavior of humpback whales in Southeast Alaska: 1981 season. Report to the National Marine Mammal Laboratory, Seattle

Baker, C. S., Herman, L. M., Perry, A., Lawton, W. S., Straley, J. M., Straley, J. H. (1985). Population characteristics and migration of humpback whales in southeastern Alaska. Mar Mamm. Sci. 1: 304-323

Baker, C. S., Herman, L. M., Perry, A., Lawton, W. S., Straley, J. M., Wolman, A. A., Kaufman, G. D., Winn, H. E., Hall, J. D., Reinke, J. M., Östman, J. (1986). Migratory movement and population structure of humpback whales (Megaptera novaeangliae) in the central and eastern North Pacific. Mar. Ecol. Prog. Ser. 31: 105-119

Bauer, G. B. (1986). The behavior of humpback whales in Hawaii and modification of behavior induced by human interventions. Ph. D. dissertation, Univ. of Hawaii, Honolulu

Bonnell, M. L., Selander, R. K. (1974). Elephant seals: genetic variation and near extinction. Science 184: 908-909

Bryant, P. J., Nichols, G., Bryant, T B., Miller, K. (1981). Krill availability and the distribution of humpback whales in southeastern Alaska. J. Mammals 62: 427-430

Carlson, C. A., Mayo, C. A. (1983). Changes in the pigment and scar patterns on the ventral surface of the flukes of humpback whales observed in the waters on the Stellwagen Bank, Massachusetts. In: Proceedings 5th Biennial Conference on the Biology of Marine Mammals, Boston (Abstract), p. 17

Chittleborough, R. G. (1958). The breeding cycle of the female humpback whale, Megaptera nodosa. Aust. J. mar. Freshwat. Res. 9: 1-18

Chittleborough, R. G. (1965). Dynamics of two populations of the humpback whale, Megaptera novaeangliae (Borowski). Aust. J. mar. Freshwat. Res. 16: 33-128

Clapham, P. J., Mayo, C. A. (in press). Reproduction and recruitment of individually-identified humpback whales, Megaptera novaeangliae, in Massachusettes Bay: 1979-1985. Can. J. Zool.

Darling, J. D., Gibson, K. M., Silber, G. K. (1983). Observations on the abundance and behavior of humpback whales (Megaptera novaeangliae) off West Maui, Hawaii, 1977-1979. In: Payne, R. (ed.) Communication and behavior of whales. Westview Press, Boulder, p. 201-222

Darling, J. D., Jurasz, C. M. (1983). Migratory destinations of North Pacific humpback whales (Megaptera novaeangliae). In: Payne, R. (ed.) Communication and behavior of whales. Westview Press, Boulder, p. 359-368 
Darling, J. D., McSweeney, D. J. (1985). Observations on the migrations of North Pacific humpback whales (Megaptera novaeangliae). Can. J. Zool. 63: 308-314

Darling, J. D., Morowitz, H. (1986). Census of 'Hawaiian' humpback whales (Megaptera novaeangliae) by individual identification. Can. J. Zool. 64: 105-111

Dawbin, W. H. (1966). The seasonal migratory cycle of humpback whales. In: Norris, K. S. (ed.) Whales, dolphins, and porpoises. Univ. of California Press, Berkeley, p. 145-171

DeLong, R. L., Gilmartin, W. G., Simpson, J. G. (1973). Premature births in California sea lions: association with high organochlorine pollutant residue levels. Science 181 $1168-1170$

Eberhardt, L. L. (1977). Optimal policies of conservation of large mammals with special reference to marine ecosystems. Environ. Conserv. 4: 205-212

Fowler, C. W (1981). Comparative population dynamics in large mammals. In: Fowler, C. H., Smith, T D. (ed.) Dynamics of large mammal populations. Wiley, New York, p. $437-456$

Gambell, R. (1973). Some effects of exploitation on reproduction in whales. J. Reprod. Fert. (Suppl.) 19: 533-553

Glockner-Ferrari, D. A., Ferrari, M. J. (1984). Reproduction in humpback whales, Megaptera novaeangliae, in Hawaian waters. In: Perrin, W. P., Donovan, G. P., DeMasters, D. P. (ed.) Reproduction in whales, dolphins, and porpoises. Rep. Int. Whal. Commn, special issue 6: 237-242

Glockner-Ferrari, D. A., Venus, S. C. (1983). Identification, growth rate, and behavior of humpback whale (Megaptera novaeangliae) cows and calves in the waters of Maui, Hawaii. In: Payne, R. (ed.) Communication and behavior of whales. Westview Press, Boulder, p. 223-258

Helle, E., Olsson, M., Jensen, S. (1976). DDT and PCB levels and reproduction in ringed seal from the Bothnian Bay. Ambio 5: 188-189

Herman, L. M., Antinoja, R. C. (1977). Humpback whales in the Hawaiian breeding waters: population and pod characteristics. Sci. Rep. Whales Res. Inst. Tokyo 29: 59-85

Herman, L. M., Forestell, P. H., Antinoja, R. C. (1980). The 1976/77 migration of humpback whales into Hawaiian waters: composite description. Marine Mammal Commission Report MMC-77/19, Washington, DC

Herrenkohl, L. R. (1979). Prenatal stress reduces fertility and fecundity in female offspring. Science 206: 1097-1099

Johnson, J. H., Wolman, A. A. (1984). The humpback whale Mar. Fish. Rev. 46: 30-37

Jurasz, C. M., Jurasz, V. P., Noble, E. L. (1981). An examination of the distribution of humpback whales (Megaptera novaeangliae) in southeast Alaska. Report to the State of Alaska Department of Fish and Game, Division of FRED, Juneau

Jurasz, C. M., Palmer, V P. (1981). Censusing and establishing age composition of humpback whales (Megaptera novaeangliae) employing photodocumentation in Glacier Bay National Monument, Alaska. Report to the National Park Service, Alaska Regional Office, Anchorage

Katona, S., Baxter, B., Brazier, O., Kraus, S., Perkins, J., Whitehead, H. (1979). Identification of humpback whales by fluke photographs. In: Winn, H. E., Olla, B. L. (ed.) Behavior of marine animals, Vol. 3. Plenum Press, New York, p. 33-44

Krieger, K., Wing, B. L. (1984). Humpback whale prey studies in Southeast Alaska, summer 1983. Northwest and Alaska Fisheries Center, Auke Bay Laboratory, Juneau

Laws, R. M. (1961). Reproduction, growth and age of southern fin whales. 'Discovery' Rep. 31: 327-486

Laws, R. M. (1973). Effects of human activity on reproduction in the wild. J. Reprod. Fert. (Suppl.) 19: 523-532
Laws, R. M. (1977). Seals and whales in the southern Oceans Phil. Trans. R. Soc. Ser. B 279: 81-96

Laws, R. M. (1981). Experiences in the study of large mammals. In: Fowler, C. H., Smith, T. D. (ed.) Dynamics of large mammal populations. Wiley, New York, p. 19-46

Leuthold, W. (1977). African ungulates. Springer-Verlag, New York

Lockyer, C. (1981). Growth and energy budgets of large baleen whales from the southern hemisphere. F.A.O. Fish Ser 5 (31): 379-487

Lockyer, C. (1984). Review of baleen whale (Mysticeti) reproduction and implications for management. In: Perrin, $W$ P., Donovan, G. P., DeMasters, D. P. (ed.) Reproduction in whales, dolphins, and porpoises. Rep. Int. Whal. Commn, special issue 6: 19-46

Mackintosh, N. A. (1942). The southern stocks of whalebone whales. 'Discovery' Rep. 22: 197-300

Martin, A. R., Katona, S. K., Matilla, D., Hembree, D., Waters, T. D. (1984). Migration of humpback whales between the Caribbean and Iceland. J. Mammal. 65: 330-333

Matsuura, Y. (1940). The constitution of whale populations in the Antarctic. III. Humpback whale. Bull. Jap. Soc. scient. Fish. 9 (2). (Japanese; English summary)

Matthews, L. H. (1937). The humpback whale, Megaptera nodosa. 'Discovery' Rep. 17: 7-92

Mitchell, E. (1974). Present status of northwest Atlantic fin and other whale stocks. In: Schevill, W. E. (ed.) The whale problem: status report. Harvard Univ. Press, Cambridge, p. 110-169

Mitchell, E. (1975). Trophic relationships and competition for food in Northwest Atlantic whales. Proc. Can. Soc. Zoologists 1974, p: 123-133

Mizroch, S. A. (1980). Some notes on Southern Hemisphere baleen whale pregnancy rate trends. Rep. Int. Whal Commn 30: 561-574

Mizroch, S. A. (1981). Further notes on Southern Hemisphere baleen whale pregnancy rate. Rep. Int. Whal Commn 31. $629-633$

Mizroch, S. A. (1983). Reproductive rates in Southern Hemisphere baleen whales. M.S. thesis, Univ. of Washington Seattle

Mizroch, S. A., York, A. E. (1984). Have pregnancy rates of Southern Hemisphere fin whales, Balaenoptera physalus, increased? In: Perrin, W P., Donova, G. P., DeMasters, D. P. (ed.) Reproduction in whales, dolphins, and porpoises. Rep. Int. Whal Commn, special issue 6:401-410

Nerini, M. K., Braham, H. W., Marquette, W. M., Rough, D. J. (1984). Life history of the bowhead whale, Balaena mysticetus (Mammalia. Cetacea). J. Zool., Lond. 204: 443-468

Nishiwaki, M. (1959). Humpback whales in Ryukyuan waters Sci. Rep. Whales Res. Inst. Tokyo 14: 49-86

Norris, K. S., Reeves, R. (1978). Report on a workshop on problems related to humpback whales (Megaptera novaeangliae) in Hawaii. Report to the U.S. Marine Mammal Commission, Washington

O'Brien, S. J., Wildt, D. E., Goldman, D., Merril, C. R., Bush M. (1983). The cheetah is depauperate in genetic variation. Science 221: 459-462

Omura, H. (1953). Biological study on humpback whales in the Antarctic whaling areas IV and V Sci. Rep. Whales Res. Inst. Tokyo 8: 81-101

Payne, M. R. (1977). Growth of a fur seal population. Phil Trans. R. Soc. Ser. B 279: 67-80

Perry, A., Baker, C. S., Herman, L. M. (1985). The natural history of humpback whales in Glacier Bay, Alaska. Final report to the National Park Service, Alaska Regional Office, Anchorage 
Ralls, K., Brugger, K., Ballou, J. (1979). Inbreeding and juvenile mortality in small populations of ungulates. Science 206: 1101-1103

Reilly, S. B. (1984). Observed and maximum rates of increase in gray whales, Eschrichtius robustus. In: Perrin, W. P., Donovan, G. P., DeMasters, D. P. (ed.) Reproduction in whales, dolphins, and porpoises. Rep. Int. Whal Commn. special issue 6: 389-399

Rice, D. W. (1963). Progress report on biological studies of the larger Cetacea in the waters off California. Norsk Hvalfangsttid. 51: 181-187

Rice, D. W. (1978). The humpback whale in the North Pacific: distribution, exploitation, and numbers. In: Norris, K. S., Reeves, R. (ed.) Report on a workshop on problems related to humpback whales (Megaptera novaeangliae) in Hawaii. Report to the U.S. Marine Mammal Commission, Washington, p. $29-44$

Rice, D. W., Wolman, A. A. (1971). The life history and ecology of gray whales, (Eschrichtius robustus). Am. Soc. of Mammal. Spec. Publ. 3: 1-142
Snedecor, G. W., Cochran, W G. (1967). Statistical methods Iowa State Univ. Press, Ames

Symons, H. W., Weston, R. D. (1958). Studies of the humpback whale (Megaptera nodosa) in the Bellingshausen Sea. Norsk Hvalfangsttid. 47 54-81

True, F. W. (1904). The whalebone whales of the western North Atlantic compared with those occuring in European waters; with some observations on the species of the North Pacific. Smithson. Contr Knowl. 33: 1-318

Tyack, P., Whitehead, H. (1983). Male competition in large groups of wintering humpback whales. Behaviour 83: 132-154

Whitehead, H. (1982). Populations of humpback whales in the Northwest Atlantic. Rep. Int. Whal. Commn 32: 345-353

Wilson, E. O. (1975). Sociobiology: the new synthesis. Harvard Univ. Press, Cambridge

Wolman, A. A., Jurasz, C. M. (1977). Humpback whales in Hawaii: vessel census 1976. Mar Fish. Rev. 39: 1-5

This article was submitted to the editor; it was accepted for printing on July 21, 1987 